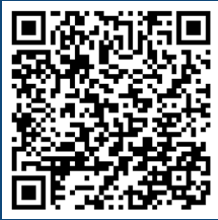

Elisa Regina da Silva ${ }^{\text {a }}$, Ingridh Medeiros Simões ${ }^{1 b+}$, Julcinara Oliveira Baptista ${ }^{2 a}$, Edilson Romais Schmildt ${ }^{3 a}$, José Carlos Lopes ${ }^{2 b}$, Elzimar de Oliveira Gonçalves ${ }^{1 c}$, Marcos Vinícius Winckler Caldeira ${ }^{\text {ld }}$, Rodrigo Sobreira Alexandre ${ }^{\text {le }}$

\title{
IN VITRO OF Melanoxylon brauna SCHOTT. MORPHOGENESIS: RESPONSIVENESS OF EXPLANTS TO PERMANENT AND TEMPORARY IMMERSION GROWTH REGULATORS
}

SILVA, E. R.; SIMÕES, I. M.; BAPTISTA, J. O.; SCHMILDT, E. R.; LOPES, J. C.; GONÇALVES, E. O.; CALDEIRA, M. V. W.; ALEXANDRE, R. S. In vitro of Melanoxylon brauna Schott. morphogenesis: responsiveness of explants to permanent and temporary immersion growth regulators. CERNE, v. 26, n. I, p.26-36, 2020.

\section{HIGHLIGHTS}

Keywords:

Brauna

Tissue culture

Polarity

Cytokine

Auxins

Historic: Received 26/12/2019 Accepted 14/03/2020

Correspondence: simoes.ingridh@gmail.com

Nodal segment with two axillary buds is the recommended explant without the use of BAP.

Apex of the stem is the explant recommended with BAP $\left(2.5-3.5 \mathrm{mg} \cdot \mathrm{L}^{-1}\right)$.

IBA, NAA and 2,4-D were not suitable for in vitro rhizogenesis in WPM medium.

Immersion of the sprout base in IBA $\left(2,500 \mathrm{mg} \cdot \mathrm{L}^{-1}\right)$ and planting in vermiculite is recommended for rooting.

\section{ABSTRACT}

Melanoxylon brauna is propagated by seeds, however, low yield, pest attack and short viability are problems in seedling production. In vitro cultivation is an alternative for large-scale seedling production, but studies with this species are scarce. The aim of the work was to analyze the in vitro morphogenesis of braúna. Explants after induction of growth regulators. Three experiments were performed: I. In vitro bud proliferation of juvenile explants at different BAP concentrations. Was analyzed the number and length of shoots $(\mathrm{mm})$; bud explants ${ }^{-1}(\%)$; calogenesis (\%) and direct and indirect organogenesis budding $^{-1}(\%)$. II. In vitro rhizogenesis of shoots with different types and auxin concentrations. III. In vitro rhizogenesis of under temporary immersion of shoots at different IBA concentrations. It was analyzed in experiment I and II: calogenesis (\%); rhizogenesis (\%); number, length $(\mathrm{mm})$ and root dry mass $(\mathrm{mg})$ the shoots. The nodal segment with two axillary buds was the most responsive explant regardless of the use of BAP. The stem apex with the use of BAP $\left(2.5-3.5 \mathrm{mg} \cdot \mathrm{L}^{-1}\right)$ was the most responsive in the proliferation of shoots. Tested concentrations of auxins IBA, NAA and 2,4-D were not sufficient for in vitro rhizogenesis. The average of the maximum technical efficiencies of the variables used to analyze rhizogenic process suggests the treatment of the shoots base by temporary immersion in the IBA at an approximate concentration of $2,500 \mathrm{mg} \cdot \mathrm{L}^{-}$ I and planting on the vermiculite substrate.

' Federal University of Espírito Santo, Jerônimo Monteiro, Espírito Santo, Brazil- ORCID: 0000-0002-5126-2196, 0000-0002-7483-9349 b, 0000-000I-7675-2493c, 0000-0003-469 I-989 I d, 0000-0002-5248-6773e

${ }^{2}$ Federal University of Espírito Santo, Alegre, Espírito Santo, Brazil- ORCID: 0000-0003-349I-5498a, 0000-00024880-0547

${ }^{3}$ Federal University of Espírito Santo, São Mateus, Espírito Santo, Brazil- ORCID: 0000-0002-3457-7997ª 


\section{INTRODUCTION}

Melanoxylon brauna belongs to the Fabaceae family and is a tree that presents wood of high density and durability and, therefore, widely used in construction, in the shipping and furniture industry (Lorenzi, 2009), reason for its intense devastation over the years, which associated with the lack of plantations culminated in their inclusion in the official list of endangered species of Brazilian flora (Crepaldi and Peixoto, 20I0; Brazil, 20I4).

The species is commonly propagated sexually, however, its seeds are very attractive to predatory insects, implying low production of viable seeds, being an obstacle to seedling production (Corte et al., 20 I0). In vitro propagation of $M$. brauna is an alternative for large-scale seedling production of high nutritional, physiological and sanitary quality, besides the maintenance of germplasm banks. In vitro cultivation, in the commercial propagation of plant species, has future priorities, including the conservation of genetic resources and the multiplication of plant resources that have valuable biologically active substances (Yancheva and Kondakova, 20I8).

The basic principle of in vitro propagation is cell totipotency, which is the ability of a cell to divide and form a whole new organism (Steward, 1983). The WUSCHEL gene (WUS) characterized by the presence of a homeodomain (WOX) has the necessary transcription factors for the maintenance of stem cells in the apical budding meristem, the differentiation of the lateral primordia, the totipotence of plant cells and other diverse cellular processes (Jha et al., 2020). In soybean (Fabaceae) the expression pattern of the GmWOX genes has a high morphogenetic capacity and, an overexpression of GmWOXI 8 increased the yolk production capacity (Hao et al., 2019). However, morphogenesis is influenced by environmental conditions in vitro, such as DNA methylation and histone modifications, which we call epigenetics (Us-Camas, 20I4).

Morphogenesis occurs directly or indirectly, whose proliferation of shoots originates directly from the explant or from undifferentiated tissues, respectively, and is divided into three distinct phases: in the first, the cells acquire competence and de-differentiate, becoming able respond to signals from regulators; in the second, the competent cells are determined to form the shoot and root system according to the auxin/cytokine balance, and in the third phase, morphogenesis occurs, which is the formation of a complete plant (George et al., 2008). Furthermore, the success of in vitro morphogenetic pathways is influenced by intrinsic factors, such as genotype, type of explant, age and size of the explant, and among the most important extrinsic factors are plant regulators, qualitatively (auxins and cytokinins) and quantitatively (concentrations) (Moreira-Dias et al., 200 I; Magyar-Tábori et al., 20 I0; Lee and Pijut, 20I7). In relation to extrinsic factors, the morphogenic response is strongly influenced by the position of the explant in the plant, and differs in polarity, considering that the closer to the cotyledonary node, the better the capacity of explant bud emission (Garcia-Luiz et al., 1999; Moreira-Dias et al., 200I). The different responsiveness of explants in relation to plant position is linked to endogenous hormone levels, in which explants farther away from auxin synthesis centers are less influenced by auxin synthesis, presenting better response in bud formation (Long and Barton, 2000). In contrast, cytokines help in the emission of shoots, being the most used in in vitro propagation, 6-benzylaminopurine (BAP), which presents the advantages of low cost and efficiency in shoot growth and induction of adventitious shoots. Concentration is the major factor in shoot emission (Koech et al., 2005). In the species Delonix regia (Bojer ex Hook.), belonging to the Fabaceae family, the same as the braúna, the buds apexes and cotyledon segments presented the highest number of buds, when the explants were grown in MS culture medium supplemented with BA $\left(2.0 \mathrm{mg} \mathrm{L}^{-1}\right)$ (Costa et al., 2020).

So, the substances responsible for rhizogenesis are auxins and, the great advance in the history of vegetative propagation was the discovery of indole-3-acetic acid (IAA), indole-3-butyric acid (IBA) and naphthaleneacetic acid (NAA), which provide higher percentage, quality, speed and uniformity of rhizogenesis (Hartmann et al., 20I I).

Studies focusing on in vitro propagation of $M$. brauna are scarce. In this perspective, the objective was to study the morphogenesis of juvenile explants after induction of growth regulators.

\section{MATERIAL AND METHODS}

The experiments were performed at the Plant Tissue Culture Laboratories of the Department of Forestry and Wood Sciences of the Center for Agrarian Sciences and Engineering, at the Federal University of Espírito Santo (UFES). Braúna (Melanoxylon brauna Schott) seeds were obtained from matrices of the municipality of LeopoldinaMG, at $21^{\circ} 59^{\prime} 75^{\prime \prime}$ S, $42^{\circ} 49^{\prime} 42^{\prime \prime} \mathrm{W}$.

\section{Experiment I: In vitro bud proliferation of juvenile}

M. brauna explants at different BAP concentrations

Yolk proliferation was stimulated in normal seedlings from $M$. brauna seeds grown in vitro for 30 days. The seeds were previously washed in running water and neutral detergent, and in a laminar flow chamber, they 
were disinfected alcohol (70\%) for one minute, and active chlorine $\mathrm{NaOCl}(2.5 \%)$ for 15 minutes, and then, the seeds were submerged in Captan ${ }^{\circledR}(2 \%)$ p.a. for 10 minutes. After treatment with agents disinfectants, the seeds were washed in distilled/autoclaved water three times. The seeds were then arranged into the test tubes containing $10 \mathrm{~mL}$ of Sigma ${ }^{\circledR}$ Woody Plant Medium (WPM) medium (2.4I $\left.\mathrm{g} \mathrm{L}^{-1}\right)$ (Lloyd and McCow, 1980), Dinamic $^{\circledR}$ sucrose $\left(30 \mathrm{~g} \mathrm{~L}^{-1}\right)$, Sigma ${ }^{\circledR}$ myo-inositol $(0.1$ $\left.\mathrm{g} \mathrm{L}^{-1}\right)$, Kasvi ${ }^{\circledR}$ agar $\left(7 \mathrm{~g} \mathrm{~L}^{-1}\right)$, whose $\mathrm{pH}$ was adjusted to $5.7 \pm 0.1$ and autoclaved for 20 minutes at a temperature of $121^{\circ} \mathrm{C}$ and a pressure of $\mathrm{I}$ atm. In vitro seeds were kept in a growth room for 30 days at $27 \pm 2^{\circ} \mathrm{C}, 16$ hours photoperiod, with $50 \mu \mathrm{mol} \mathrm{m} \mathrm{m}^{-2} \mathrm{~s}^{-1}$ irradiance promoted by $20 \mathrm{~W}$ tubular LED lamps.

Normal seedlings were sectioned with the aid of sterile stainless-steel scalpel blades at different positions of the epicotyl. The excised explants were: stem apex; nodal segment with an axillary bud; nodal segment with two axillary buds and cotyledonary node. The explants were inserted into test tubes containing culture medium supplemented with 6-benzylaminopurine (BAP) Sigma ${ }^{\circledR}$ at concentrations of $0 ; 2 ; 4 ; 6$ and $8 \mathrm{mg} \mathrm{L}^{-1}$. They were subsequently kept for 60 days in a growth room.

The experiment was carried out in a completely randomized design in a $4 \times 5$ factorial scheme with four explant types and five BAP concentrations. The characteristics analyzed were number of shoots, length of shoots $(\mathrm{cm})$, explants with budding (\%), calogenesis (\%) and number of shoots by direct and indirect organogenesis.

Data were subjected to analysis of variance and Tukey test $(p<0.05)$ for explant factor and regression to concentrations of BAP, using the statistical software $R(R$ CORE TEAM, 2017).

Experiment II: In vitro rhizogenesis of $M$. brauna with different auxin types and concentrations

The experiment was carried out in a completely randomized design in a $3 \times 4$ factorial scheme with three types of auxins (IBA - indole-3butyric acid; NAA - naphthaleneacetic acid and 2,4-D 2,4-dichlorophenoxyacetic acid) at concentrations of 0 ; I; 2 and $3 \mathrm{mg} \mathrm{L}^{-1}$, with six repetitions of four shoots. The culture medium used consisted of $2.4 \mathrm{I} \mathrm{g} \mathrm{L}^{-1}$ WPM (same as above).

Auxins were filtered and added to the already autoclaved culture medium in Erlenmeyer when they reached a temperature of $50^{\circ} \mathrm{C}$. Subsequently, $30 \mathrm{~mL}$ of the culture medium was poured into $350 \mathrm{~mL}$ capacity glass vials and sealed with PVC film, kept in the growth room in the dark for five days at $27 \pm 2^{\circ} \mathrm{C}$ to avoid auxin photodegradation and allow absorption by the explants and analyze their contamination.

The approximately one centimeter long M. brauna shoots from bud proliferation were kept in flasks with culture medium for a further 60 days under a 16-hour photoperiod and $50 \mu \mathrm{mol} \mathrm{m}^{-2} \mathrm{~s}^{-1}$ irradiance.

The characteristics analyzed were: calogenesis (\%) and rhizogenesis (\%). Data were subjected to analysis of variance and regression $(p<0.0 \mathrm{I})$ using the statistical software $R$ (R CORE TEAM, 2017).

Experiment III: In vitro rhizogenesis of $M$. brauna under temporary bud immersion at different IBA concentrations

The experiment was carried out in a completely randomized design with five IBA concentrations $(0 ; 1,000$; 2,000; 3,000 and $\left.4,000 \mathrm{mg} \mathrm{L}^{-1}\right)$ and four replications of six shoots each.

The bud sprouts from the bud proliferation were immersed for 10 seconds at each IBA concentration, and then inserted into test tubes containing $1 / 3$ volume of the tube with moist and autoclaved vermiculite (for 30 minutes at $121{ }^{\circ} \mathrm{C}$ and pressure at $\mathrm{I} \mathrm{atm}$ ), and kept in a growth room for 30 days at $27 \pm 2{ }^{\circ} \mathrm{C}, 16$ hour photoperiod and $50 \mu \mathrm{mol} \mathrm{m}^{-2} \mathrm{~s}^{-1}$ irradiance.

The characteristics analyzed were: rooting (\%), number of roots, root length $(\mathrm{cm})$ and root dry mass (mg). Data were subjected to analysis of variance and regression analysis $(\mathrm{p}<0.0 \mathrm{I})$ using the $R$ statistical software (R CORE TEAM, 20I7).

\section{RESULTS AND DISCUSSION}

Experiment I: In vitro bud proliferation of juvenile M. brauna explants at different BAP concentrations

The axillary segment with two buds was the explant with the highest morphogenetic activity, observed in the number of shoots (2.7) (Figure la), which emitted $95 \%$ of explants with budding (Figure Ib) and $92 \%$ of the shoots by direct organogenesis (Figure Ic). These two pre-existing buds in the axillary segment have greater emergence potential, which culminates in bud formation and, this is due to the internal signaling of plant hormones (Dierck et al., 2016). And, according to these authors, the important thing is the balance between auxins, cytokinins and strigolactones, in which auxins are transported basipetally and indirectly inhibit the axillary growth of shoots, restricting the export 
of auxins from axillary shoots to the stem or inducing biosynthesis strigolactone and limiting cytokinin levels. Axillary meristems (MAs) derive from a stem cell line that is maintained in the leaf axilla, in which its initiation is controlled by transcription factors, phytohormones, and epigenetic regulation (Cao and Jiao, 2019). In Brassica napus L., 27,992 expressed genes were identified, of which 479 were considered closely related to the development of axillary buds (Li et al., 2020).

The explants responsiveness (Figure I) was obtained in descending order, axillary segment with two

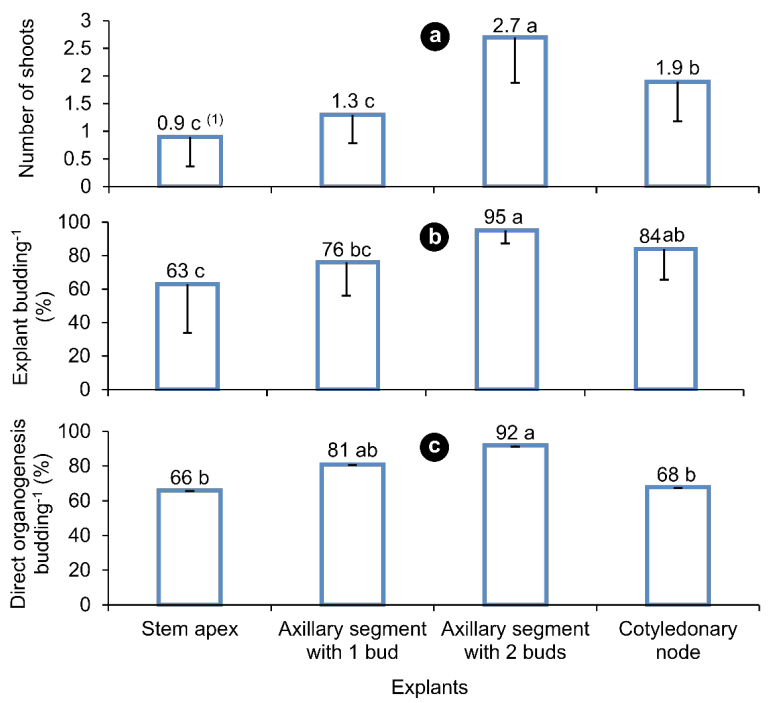

FIGURE I Sprouts in juvenile explants of $M$. brauna, regardless of BAP concentrations used. (I)Means \pm standard deviation followed by the same letter between explants do not differ by Tukey's test $(\mathrm{p}<0.05)$.

buds, cotyledonary node, axillary segment with one bud and cauline apex, different responses that may be related to the positioning of the explants, considering that the farther from the node cotyledonary is its organogenic capacity (Moreira-Dias et al., 200I) and may be related to the endogenous level of cytokine in the seedling (Schinor et al., 2006).

The highest number of shoots (2.0) and the highest percentage of explants with shoots $(89 \%)$ were obtained with the MTEs of 3.21 and $2.55 \mathrm{mg} \mathrm{L}^{-1}$ (BAP), respectively (Figure $2 \mathrm{a}$ and $\mathrm{b}$ ). The budding explants and cotyledon segments of $D$. regia (Fabaceae) increased their fresh mass and number of shoots with increasing BA concentrations (Costa et al., 2020). According to these authors, the highest number of shoots was observed in explants grown in MS medium with BA (2.0 $\left.\mathrm{mg} \mathrm{L}^{-1}\right)$. Cytokinins such as zeatin, isopentenyl adenine (2-iP), kinetin or thidiazuron (TDZ) were inferior to BA

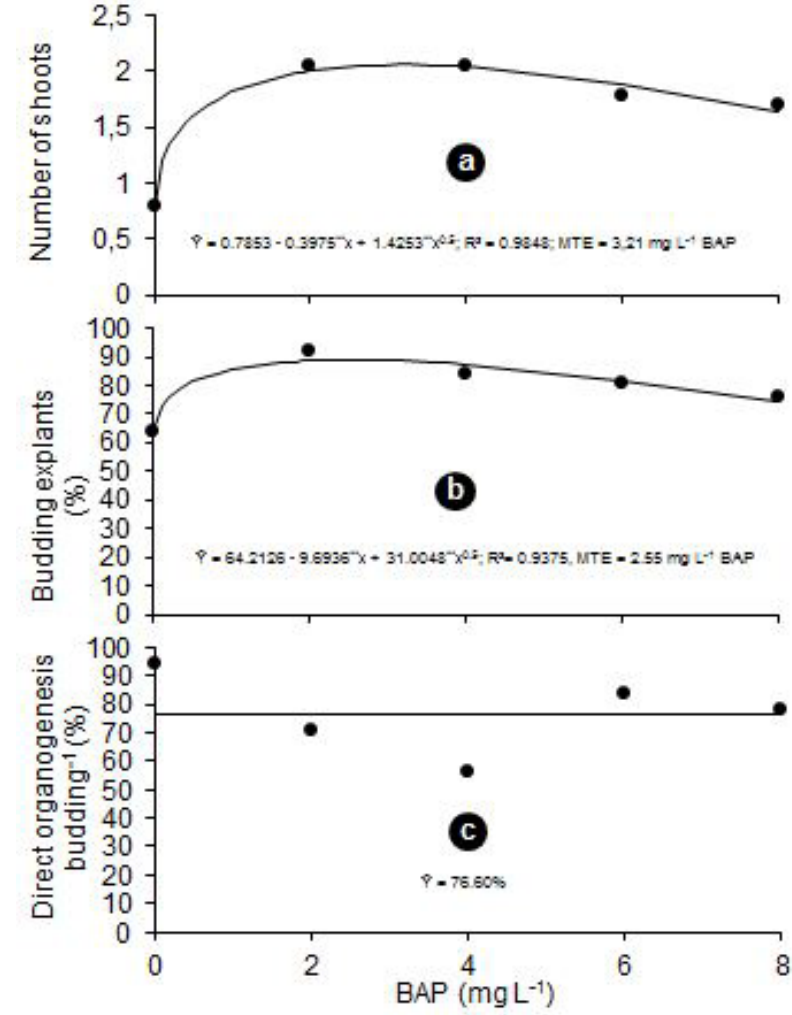

FIGURE 2 Sprouts in juvenile explants of $M$. brauna induced at different BAP concentrations independent of the explants used. a. Number of shoots; b. Budding explants (\%); c. Direct organogenesis budding-I (\%); Abbreviations: BAP. 6-benzylaminopurine; MTE. Maximum technical efficiency. ${ }^{*}$ Significant at $p<0.0$ I probability level by the $\mathrm{F}$ test.

to induce multiple sprouts of Bixa orellana L. (Siril and Joseph, 2013).

In culture medium without BAP, the number of shoots formed was 0.78 (Figure 2a), in $64.21 \%$ of the explants that sprouted (Figure $2 b$ ). The percentage of shoots via direct organogenesis showed no difference between the studied concentrations of BAP with an average of $76.60 \%$ (Figure $2 c$ ). Even in juvenile explants, the sum of synthetic cytokine (BAP) to zeatin showed a synergistic effect on the organogenic response of $M$. brauna. The results obtained are extremely important, since it identified the requirement for a concentration of cytokines for juvenile brauna explants, which can reduce the occurrence of physiological changes, such as hyperhydricity, which are usually induced from high concentrations of this regulator of growth (MagyarTábori et al., 2010). Other cytokinins may be more reactive than BA (Phillips and Garda, 2019), for example, TDZ (thidiazuron) which produces hyperhydric sprouts in plants (Dewir et al., 20I8). However, Hussain et al. (20I8) identified that BA not only mitigated the 
deleterious effects of prolonged exposure to TDZ, but also increased the multiplication rate.

According to Nunes et al. (2002) cytokine acts on breaking dormancy of shoots, therefore, explants without contact with BAP showed small number of shoots (Table 3 ). In vitro multiplication, cytokine acts by controlling the balance between cell division and differentiation through the influence of $\mathrm{GI} / \mathrm{S}$ and $\mathrm{G} 2 / \mathrm{M}$ phases during mitosis (Uzelac et al., 2012). The use of culture medium with high cytokine concentrations for an extended period changes the balance of this hormone inside the plant and can activate genes related to the formation of cytokine oxidases/dehydrogenases (CKX) enzyme, which catalyzes and degrades the metabolism of this hormone, leaving it is inactive for the plant (Yang et al., 2003; Miyawaki et al., 2006; Macková et al., 20I3).

From a 30 -day-old in vitro $M$. brauna seedling it is possible to extract a nodal segment with two axillary buds, on average three nodal segments with one axillary bud, one cotyledonary node and one stem apex (Figure 3d). Therefore, the multiplication rate from one seedling through the explants individualization is: stem apex, 0.9 explant shoots $^{-1}(0.9$ shoots $x$ I stem apex); axillary segment with one bud, 3.9 explant shoots ${ }^{-1}$ ( 1.3 shoots $\times 3$ segments); axillary segment with two buds, 2.7 explant shoots ${ }^{-1}(2.7$ shoots $x$ I segment); and cotyledonary node, 1.9 explant shoots ${ }^{-1}$ ( 1.9 shoots $x$ I cotyledonary node). The organogenic capacity of $M$. brauna seedling is 9.4 shoots, which will give rise to 9 new seedlings of this species.

The obtaining of shoots by direct organogenesis does not go through the callus formation, and the sprout comes directly from the explant (Figure $3 f$ ), reducing the time for the formation of the shoots.

Phytoregulators added to the culture medium are readily transported to the apical end of the explant, but position (apical-basal) and genotype may affect morphogenetic capacity. Studies report that segments of Troyer citrange epicotyl arranged vertically in the culture medium produce buds that arise from the vascular cambium without going through calogenesis, and when they are planted inverted, where the apex is in contact with the medium, morphogenesis is indirect, from the calogenic tissue (Garcia-Luis et al., 1999).

Leaf axillary regions have active centers, with the same potential for bud formation as the apical meristem, however, the resumption of activity of these centers occurs in acropetal order, that is, from the region closest to the cotyledonary node to the most distant region (Long and Barton, 2000), which may be associated with the movement of auxin that is produced in the apical meristem and is transported to the roots, resulting in

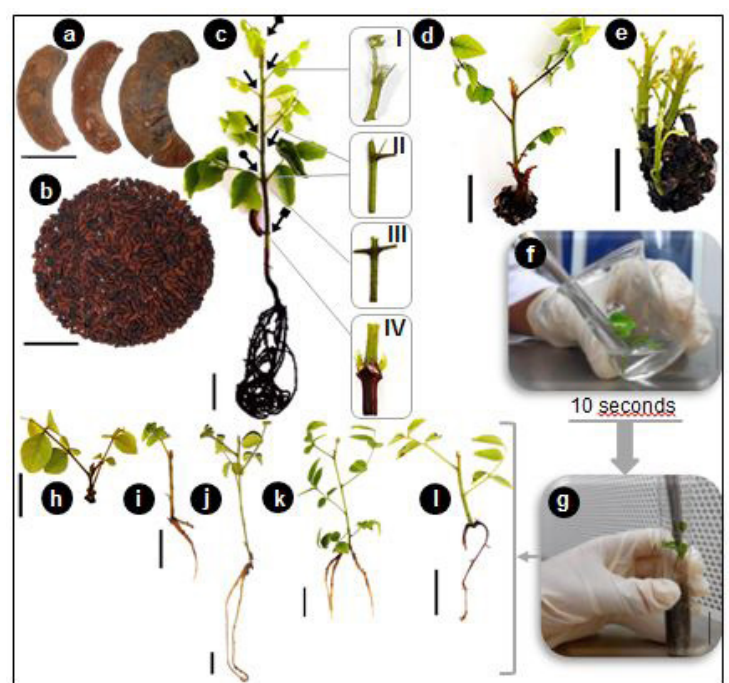

FIGURE 3 M. brauna. a. Fruits. b. Ripe seeds. c. Seedling grown in vitro 30 days after germination: I. Stem apex; II. Nodal segment with an axillary bud; III. Nodal segment with two axillary buds. IV. Cotyledonary node. d. Bud proliferation by direct organogenesis. e. Bud proliferation by indirect organogenesis. f. Temporary immersion ( 10 seconds) of shoots at a concentration of IBA. g. Bud in vermiculite for rooting. Rhizogenesis at a concentration of 0 (h); I,000 (i); 2,000 (j); 3,000 (k) and 4,000 (I) $\mathrm{mg} \mathrm{L}^{-1}$ of IBA. Bars: a. $2 \mathrm{~cm}$; b. $5 \mathrm{~cm}$; c-e. $\mathrm{I} \mathrm{cm} ; \mathrm{f}-\mathrm{g} .5 \mathrm{~cm} ; \mathrm{h}^{-1} . \mathrm{I} \mathrm{cm}$.

an adequate hormonal balance, leading to this tissue morphogenetic activity.

The axillary segment with two buds grown in vitro in medium supplemented with BAP $\left(2 \mathrm{mg} \mathrm{L}^{-1}\right)$ (Table I) resulted in one of the highest percentages of calogenesis, smaller shoots produced by indirect organogenesis, consequently the longest shoot length. The lower production of shoots by indirect means allows less competition which favors growth. The mechanism of action of auxin on blocking development of axillary buds is not fully elucidated, but inhibition is known to occur indirectly (Booker et al., 2003). Unlike auxins, cytokines are directly linked to the development of axillary buds by stimulating cell division, expansion and differentiation (Dello-loio et al., 2008).

Callus formation in organogenesis is an important process for indirect plant formation. The same arises with the disordered growth of cells, and they have active cell division centers which, under appropriate conditions, are capable of producing organs, and the competent cells, which are capable of responding to certain stimuli, differentiate and form buds. or roots (George et al., 2008).

The largest calogenesis in $M$. brauna was $79.88 \%$ (stem apex), $87.93 \%$ (axillary segment with one yolk) and 99.23\% (axillary segment with two yolks) in METs of 1.94; 
TABLE I Induction and growth of M. brauna shoots by organogenesis of different explants and BAP concentrations.

\begin{tabular}{|c|c|c|c|c|c|}
\hline & \multicolumn{5}{|c|}{$\operatorname{BAP}\left(m g \cdot L^{-1}\right)$} \\
\hline & 0 & 2 & 4 & 6 & 8 \\
\hline Explants & \multicolumn{5}{|c|}{ Calogenesis (\%) } \\
\hline Stem apex & $16.6 \pm 23.5 b^{(1)}$ & $79.1 \pm 21.9 \mathrm{a}$ & $79.1 \pm 20.9 \mathrm{ab}$ & $25.0 \pm 09.6 \mathrm{a}$ & $20.8 \pm 08.3 b$ \\
\hline Axillary segment with I bud & $37.5 \pm 34.3 \mathrm{ab}$ & $87.5 \pm 08.3 a$ & $79.1 \pm 25.0 \mathrm{ab}$ & $50.0 \pm 23.5 \mathrm{a}$ & $29.1 \pm 08.3 b$ \\
\hline Axillary segment with 2 buds & $62.5 \pm 36.9 \mathrm{a}$ & $95.8 \pm 08.3 \mathrm{a}$ & $100.0 \pm 0.0 \mathrm{a}$ & $50.0 \pm 23.5 a$ & $50.0 \pm 23.5 \mathrm{ab}$ \\
\hline Cotyledonary node & $25.0 \pm 21.5 \mathrm{ab}$ & $58.3 \pm 28.8 \mathrm{a}$ & $54.1 \pm 20.9 b$ & $33.3 \pm 36.0 \mathrm{a}$ & $79.1 \pm 15.9 a$ \\
\hline Médias & 35.4 & 80.2 & 78.1 & 39.5 & 44.7 \\
\hline Explants & \multicolumn{5}{|c|}{ Indirect organogenesis budding ${ }^{-1}(\%)$} \\
\hline Stem apex & $0.0 \pm 0.0 \mathrm{a}$ & $55.8 \pm 29.9 a$ & $52.5 \pm 33.3 \mathrm{ab}$ & $26.6 \pm 18.0 \mathrm{a}$ & $12.5 \pm 25.0 \mathrm{~b}$ \\
\hline Axillary segment with I bud & $0.0 \pm 0.0 \mathrm{a}$ & $27.9 \pm 26.2 \mathrm{ab}$ & $47 . I \pm 25.1 \mathrm{ab}$ & $14.5 \pm 13.8 \mathrm{a}$ & $06.2 \pm 12.5 b$ \\
\hline Axillary segment with 2 buds & $0.0 \pm 0.0 \mathrm{a}$ & $09.0 \pm 06.9 b$ & $17.2 \pm 20.2 b$ & $02.7 \pm 05.5 a$ & $11.0 \pm 18.4 \mathrm{~b}$ \\
\hline Cotyledonary node & $0.0 \pm 0.0 \mathrm{a}$ & $21.0 \pm 06.5 a b$ & $57.5 \pm 25.0 \mathrm{a}$ & $21.2 \pm 16.1 \mathrm{a}$ & $58.5 \pm 33.5 \mathrm{a}$ \\
\hline Médias & 0.0 & 28.4 & 43.5 & 16.3 & 22.0 \\
\hline Explants & \multicolumn{5}{|c|}{ Shoot length $\mathrm{mm}$ ) } \\
\hline Stem apex & $1.7 \pm 0.14 b$ & $6.1 \pm 0.13 b$ & $6.7 \pm 0.15 a$ & $7.8 \pm 0.40 \mathrm{a}$ & $4.1 \pm 0.17 a$ \\
\hline Axillary segment with I bud & $5.8 \pm 0.3 \mathrm{lab}$ & $7.8 \pm 0.12 b$ & $7.6 \pm 0.25 a$ & $5.8 \pm 0.18 a$ & $5.6 \pm 0.32 \mathrm{a}$ \\
\hline Axillary segment with 2 buds & $5.8 \pm 0.29 \mathrm{ab}$ & $12.3 \pm 0.21 \mathrm{a}$ & $8.7 \pm 0.19 a$ & $5.8 \pm 0.13 a$ & $6.4 \pm 0.2 \mathrm{Ia}$ \\
\hline Cotyledonary node & $6.1 \pm 0.27 a$ & $5.3 \pm 0.14 \mathrm{~b}$ & $6.8 \pm 0.22 a$ & $7.7 \pm 0.10 a$ & $5.6 \pm 0.12 a$ \\
\hline Médias & 4.8 & 7.8 & 7.4 & 6.7 & 5.4 \\
\hline
\end{tabular}

(I)Means \pm standard deviation followed by the same letter in the column between different types of explants do not Tukey's teste ( $<<0.05)$.

1.83 and $1.60 \mathrm{mg} \cdot \mathrm{L}^{-1}$ (BAP), respectively. However, for the cotyledon node explant, the percentage of callogenesis showed no difference between the studied concentrations of BAP with an average of $49.94 \%$ (Figure $4 a$ ).

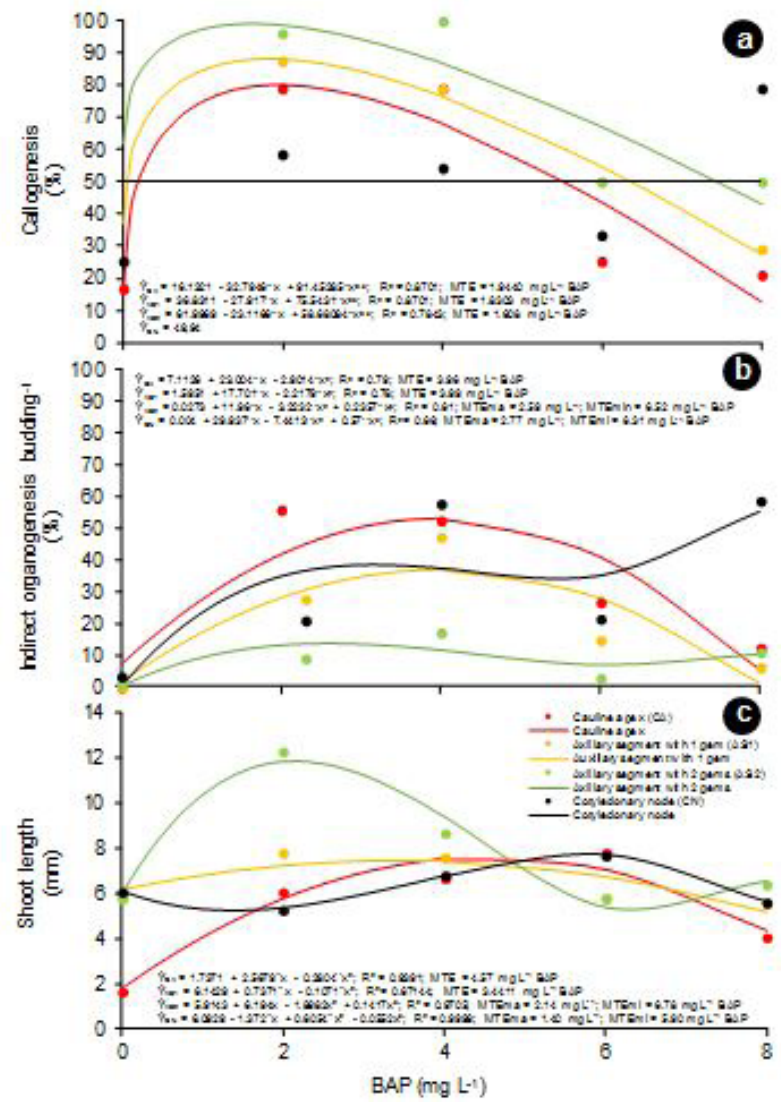

FIGURE 4 Induction and growth of $M$. brauna shoots by organogenesis of different explants and BAP concentrations. a. Callogenesis (\%); b. Indirect organogenesis budding-1 (\%); c. Shoot length ( $\mathrm{mm}$ ). Abbreviations: BAP. 6-benzylaminopurine; MTE. Maximum technical efficiency; MTEma. Maximum technical efficiency - maximum point; MTEmi. Minima technical efficiency - minino point. **Significant at $\mathrm{p}<0.0$ I probability level by the $\mathrm{F}$ test.
The highest percentages of $M$. brauna shoots via indirect organogenesis were obtained in the explants stem apex $(52.7 \%)$ and axillary segment with one yolk (36.9\%), in a quadratic model with MET of $3.9 \mathrm{mg} \cdot \mathrm{L}^{-1}$ (BAP) (Figure 4b). The axillary segment with two buds (I3.47\%) and the cotyledon node (\%), presented the lowest percentage of shoots via indirect organogenesis, identified in a cubic model with METs of 2.59 and $2.77 \mathrm{mg} \cdot \mathrm{L}^{-1}$ (BAP), respectively (Figure 4b). In Genipa americana $\mathrm{L}$. high sprouting rates $(80 \%)$ were produced in hypocotyl segments with BAP $\left(1.12 \mathrm{mg} \cdot \mathrm{L}^{-1}\right)$ (Souza et al., 2019). Chinnaraj and Malimuthu (201 I) the initiation rate of shoots of $D$. sissoo (Fabaceae) is low (36\%), using BAP (I mg. $\left.\mathrm{L}^{-1}\right)$ and in the multiplication with the reduction of BAP to $0.15 \mathrm{mg} \cdot \mathrm{L}^{-1}$ the average number of shoots was three. Vibha et al. (2014), used nodal segments of adult trees (20-25 years) from Dalbergia sissoo Roxb. at the initiation of organogenesis in solid medium with BAP (2.0 mg. L-1), however, multiple sprouts (2I per node) were obtained in liquid medium supplemented with BAP $\left(0.5 \mathrm{mg} \cdot \mathrm{L}^{-1}\right)+$ TDZ $(0.00044$ $\left.\mathrm{mg} \cdot \mathrm{L}^{-1}\right)$ (Vibha et al., 2014).

The size of the M. brauna bud from the stem apex explants $(7.6 \mathrm{~mm})$ and axillary segment with a yolk $(7.4 \mathrm{~mm})$ presented a quadratic model, with MTEs of 4.57 and $3.44 \mathrm{mg} \cdot \mathrm{L}^{-1}$ (BAP), respectively. The size of shoots from the axillary segment explants with two buds (I $1.86 \mathrm{~mm})$ and cotyledon node $(7.73 \mathrm{~mm})$ presented a cubic model, with METs of 2.14 and $5.90 \mathrm{mg} \cdot \mathrm{L}^{-1}$ of BAP, respectively (Figure 4c). In D. sissoo, the size of the bud at the beginning of organogenesis (BAP $=2.0 \mathrm{mg} \cdot \mathrm{L}^{-}$ ') was $15 \mathrm{~mm}$ and at multiplication (BAP $\left.=0.5 \mathrm{mg} \cdot \mathrm{L}^{-1}\right)$ + TDZ $=0.00044 \mathrm{mg} \cdot \mathrm{L}^{-1}$ ) was $25 \mathrm{~mm}$ (Chinnaraj and Malimuthu, 20II). 
Experiment II: In vitro rhizogenesis of $M$. brauna with different auxin types and concentrations

Callogenesis was high in the absence of auxins with an average of $97.4 \%$ (Figure $5 a, b, c$ ). Callogenesis using NAA and 2,4-D auxins presented quadratic models, with MET of $1.5 \mathrm{mg} \cdot \mathrm{L}^{-1}$ (Figure $5 \mathrm{~b}$, $d$, respectively). Rhizogenesis was null with the use of IBA in all concentrations studied. And the rhizogenesis in medium supplemented with NAA and 2,4-D, was I.5 and $3 \%$, regardless of the concentration studied (Figure 5c, e). In blueberries (Vaccinium corymbosum), the use of IBA in concentrations of 0.1 ('Ozarkblue'); 0.5 ('Weiwa Kuahuat') and $1.0 \mathrm{mg} \cdot \mathrm{L}^{-1}$ in WPM $1 / 2$ resulted in $97.7 \%$ (6.5 roots), $84.0 \%$ (3.0 roots) and $100.0 \%$ (5.9 roots ) (Guo et al., 2019). This shows that in some species, such as $M$. brauna, the requirement for auxins for the rhizogenic process must be very low, in millimolar or micromolar concentrations.

Adventitious roots form in response to various stimuli, such as injury, stress, or growth regulators, and can develop from various tissues and cells, and typically emerge from organs such as leaves and stems (Druege et al., 2016). Rhizogenesis induction is characterized by the reprogramming of target cells to meristematic cells, the root meristemoids, which undergo successive cell divisions until the formation of internal root meristems. After the induction phase, initiation occurs, in which root primordia are formed and develop until root emergence (Costa et al., 2013; Guan et al., 20I5).

Auxins IBA, NAA and 2,4-D at concentrations of I; 2 and $3 \mathrm{mg} \cdot \mathrm{L}^{-1}$ were probably insufficient to induce stem cell reprogramming. In addition to the inefficiency of auxins at these concentrations, non-rooting and high calogenesis of $M$. brauna shoots may also be associated with the low endogenous level of IAA and the possible hormonal imbalance promoted by BAP absorbed in the process prior to rhizogenesis. Residual concentrations of cytokine in plant tissues from the organogenic process in BAP-supplemented media are believed to interact with auxins and cells were unable to express the necessary competence, ie, the imbalance between auxin and cytokine (Skoog and Miller, 1957) inhibited the cells from following the rhizogenesis pathway.

The reduced efficiency of auxins NAA and IBA at concentrations 0 ; I; 2; 3 and $4 \mathrm{mg} \cdot \mathrm{L}^{-1}$ has been reported by Soares et al. (2007) by submitting shoots obtained in vitro from mangabeira (Hancornia speciosa Gomes) stem explants. The authors suggested that the negative response obtained in rhizogenesis was probably due to the low
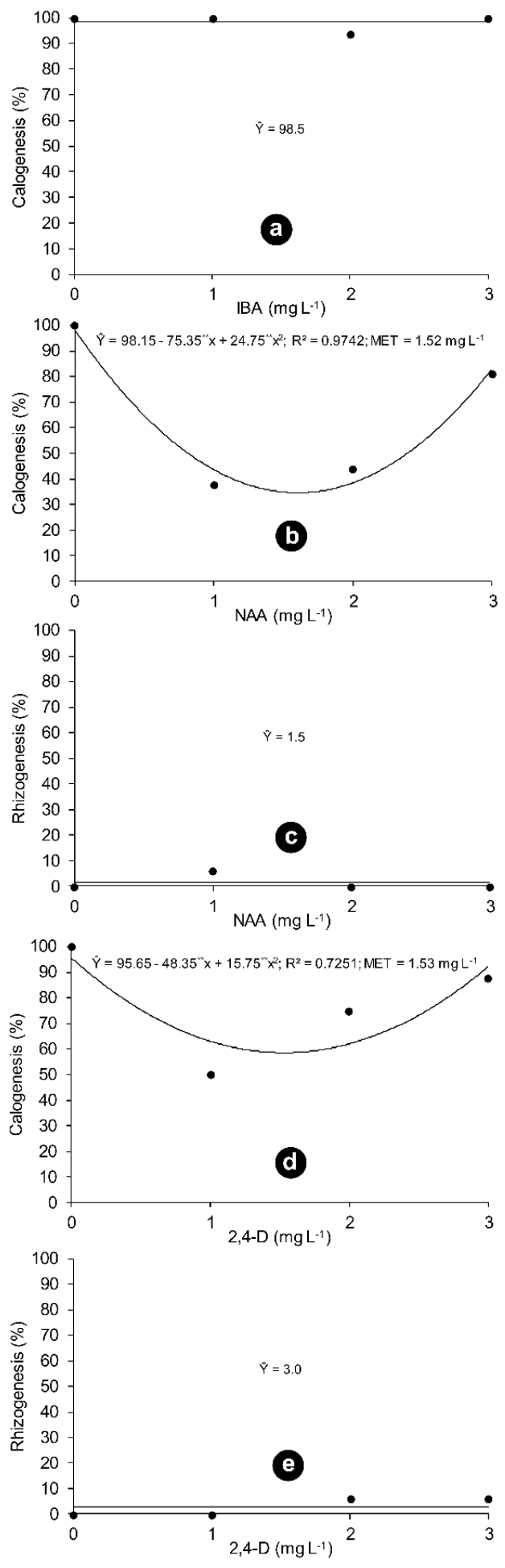

FIGURE 5 In vitro calogenesis and rhizogenesis of $M$. brauna shoots in different types and auxin concentrations. a. Calogenesis in IBA, b. in NAA; c. Rhizogenesis in NAA, d. in 2,4-D; e. in 2,4-D. Abbreviations: IBA indole-3butyric acid; NAA. naphthaleneacetic acid; 2,4-D. 2,4-dichlorophenoxyacetic acid; MTE. Minimum technical efficiency. ${ }^{*}$ Significant at $p<0.0$ l probability level by the $\mathrm{F}$ test. 
efficiency of auxins in the tested concentrations coupled with reduced endogenous levels of auxin IAA, which is the natural hormone responsible for rhizogenesis.

Stem apexes and tender leaves are the main sites of auxin synthesis. Auxinic transport occurs in two ways in the plant, the first by movement between phloem cells and the second by transmembrane proteins by the influx of efflux transporters, that is, from extracellular to intracellular, such as AUXI and PIN proteins. Thus, rooting is affected by the endogenous auxin content and its concentration (Peret et al., 2012). Root formation occurs after seven to 30 days and can be divided into three stages: induction, initiation and root elongation (Taiz et al., 2017). Therefore, the induction and initiation process are dependent on high auxin concentrations in the basal region of the stem, at which the activation of metabolism and biochemical activity occurs, while in the root elongation phase auxin becomes an inhibitor (Costa et al., 20I3).

Experiment III: In vitro rhizogenesis of M. brauna under temporary bud immersion at different IBA concentrations

All variables analyzed presented quadratic behavior (Figure 6). In the absence of IBA rooting is very low $(5.71 \%)$ (Figure 6a). The maximum technical efficiency (MTE) was obtained at concentrations of $2,544.81 ; 2,607.52 ; 2,283.33$ and $2,300.47 \mathrm{mg} \mathrm{L}^{-1}$ of IBA, which provided respectively the highest rooting (92.42\%); higher number of roots (1.52); longer root length $(17.29 \mathrm{~mm})$ and higher root dry mass $(9.162 \mathrm{mg})$ (Figure $6 \mathrm{a}-\mathrm{d}$ ), after 10 seconds of immersion of the base of the explant. The highest ex vitro rhizogenesis (80\%) was achieved in shoots of Syzygium cumini (L.) Skeels treated with IBA (40.64 $\mathrm{mg} \mathrm{L}^{-1}$ ) for 30 minutes (Naaz et al., 2019). Nodal shoots of shoots of Nyctanthes arbortristis L. pre-incubated in solid medium MS $1 / 2$ with IBA (I.2I $\mathrm{mg} \mathrm{L}^{-1}$ ) for I week, followed by planting in solid medium $M S 1 / 2$ free of growth regulator, produced 6.20 roots per explant (Ratha et al., 2020). The average of the MET of the variables used to analyze the $M$. brauna rhizogenic process suggests the treatment of the shoots base by temporary immersion in IBA at an approximate concentration of $2,500 \mathrm{mg} \cdot \mathrm{L}^{-1}$.

Synthetic auxins, for example, 2,4-dichlorophenoxyacetic acid (2,4-D) and picloram (PIC; 4-amino-3,5,6-trichloropicolinic acid), are more potent (10-1000 times) and IBA if compared to natural auxins such as indole-3-acetic acid (IAA) and this varies with species (Phillips and Garda, 2019). This explains the positive response of IBA (synthetic) at concentrations

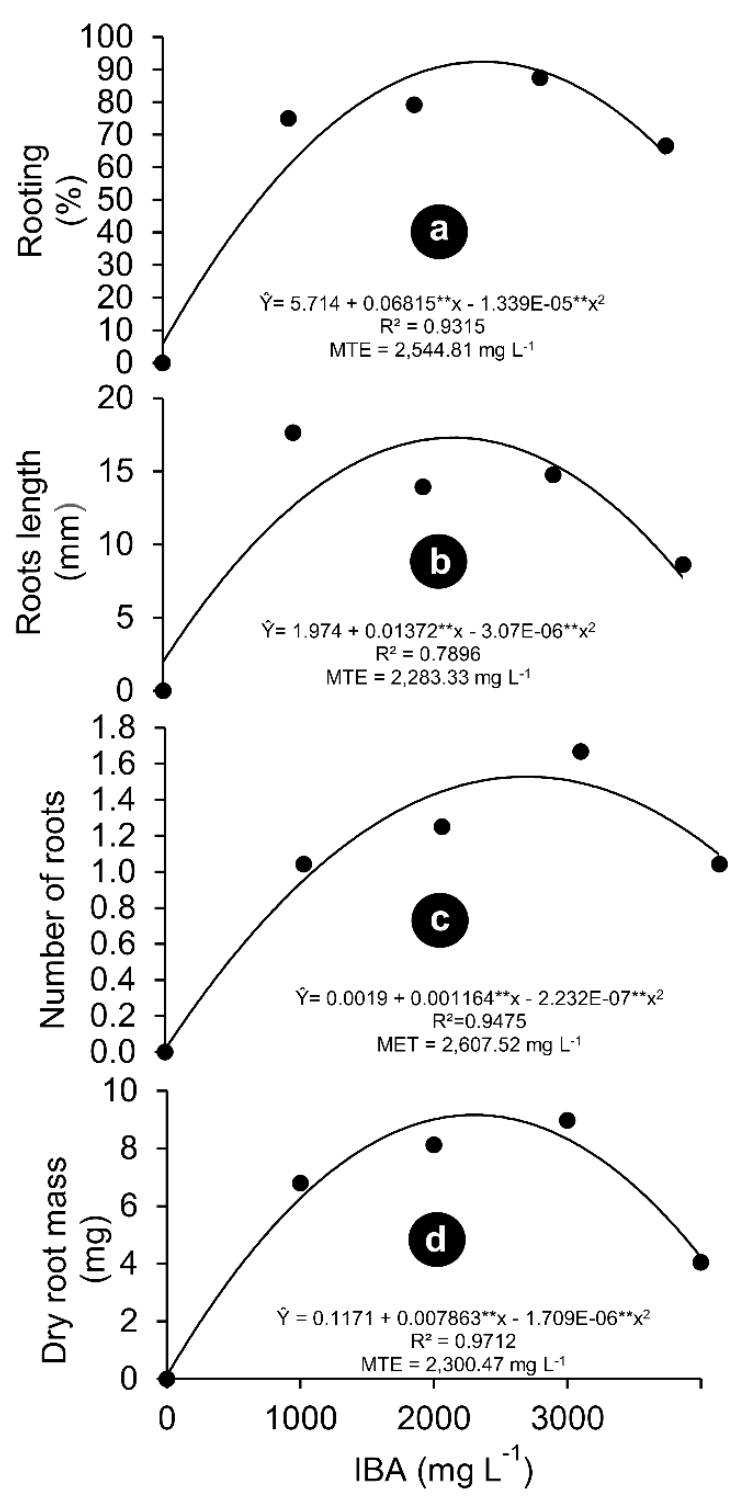

FIGURE 6 In vitro rhizogenesis of $M$. brauna shoots at different IBA concentrations. a. Rooting (\%); b. Number of roots; c. Root length (mm); d. Dry root mass (mg). Abbreviations: IBA. Indole-3-butyric acid; MTE. Maximum technical efficiency. ** Significant at $\mathrm{p}<0.0$ I probability level by the $\mathrm{F}$ test.

ranging from $2,300.47$ to $2,607.52 \mathrm{mg} \cdot \mathrm{L}^{-1}$ when the base of the shoots was immersed only 10 seconds in these solutions and planted in vermiculite substrate (Figure 6 a-d). The present research reduces the stages of in vitro propagation in culture medium for the establishment (basal medium) and organogenesis (medium with cytokines), since the rhizogenesis process is conducted in a commercial substrate.

Auxin is the main plant hormone responsible for adventitious rhizogenesis, required at high concentrations in the induction phase. After this phase, 
its requirement decreases and acts on cellular stretching, allowing the root to grow in thickness and length. In the induction phase, auxin acts as a stimulant of adventitious rhizogenesis, requiring high concentrations of this growth regulator; however, in subsequent phases, high concentrations of auxin may inhibit growth and roots do not develop (Verstraeten et al., 20l4).

Biochemical markers of adventitious rhizogenesis in Bacopa monnieri (L.) Wettst. identified that peroxidase (POX) activity during the induction phase is higher in IBA supplemented medium (I $\mu \mathrm{M}$ ) (Goel et al., 20I8). This enzyme interacts with phenols in rhizogenic induction (Lee et al., 1982). Goel et al. (2018) observed lower activities of the enzymes polyphenoloxidase (PPO), ascorbate peroxidase (APx) and indole acetic acid oxidase (IAIO) in the induction phases. The explanation for PPO and APx enzymes is that they require more monophenolic compounds, which interact with auxins in rhizogenic induction. According to Hartmann et al. (20II) the highest levels of IAAO are verified during the phases after rhizogenesis, since they are probably involved with auxin oxidation and inactivation.

Exposure of the shoots to high concentrations of IBA ( I,000; 2,000; 3,000 and 4,000 $\left.\mathrm{mg} \cdot \mathrm{L}^{-1}\right)$ for a short time contributed to the stem cells being reprogrammed to form the root meristemoids, and consequently to initiate the process of rhizogenesis. And in the stretching phase, it is believed that the shoots have already absorbed all necessary auxin, and the cultivation medium, in this case, vermiculite, is in adequate physical conditions (density and porosity) for root growth.

\section{CONCLUSIONS}

I. The nodal segment with two axillary buds was the most responsive explant regardless of the use of BAP.

II. The stem apex with the use of BAP $(2.5-3.5 \mathrm{mg}$ $\left.\mathrm{L}^{-1}\right)$ was the most responsive in the proliferation of shoots.

III. Tested concentrations of auxins IBA, NAA and 2,4-D were not sufficient for in vitro rhizogenesis.

IV. The average of the maximum technical efficiencies of the variables used to analyze the $M$. brauna rhizogenic process suggests the treatment of the shoots base by temporary immersion in the IBA at an approximate concentration of $2,500 \mathrm{mg} \cdot \mathrm{L}^{-1}$ and planting on the vermiculite substrate.

\section{AKNOWLEDGEMENTS}

The authors would like to thank FAPES/SEAG Public Notice No. 06/2015, for funding research and $\mathrm{CNPq}$ for granting the research grant.

\section{REFERENCES}

BOOKER, J.; CHATFIELD, S.; LEYSER, O. Auxin acts in xylemassociated or medullary cells to mediate apical dominance. The Plant Cell, v. I5, n. 2, p. 495-507, 2003.

BRASIL. Ministério do Meio Ambiente. Portaria $n^{\circ} 443$, de 14 de dezembro de 20/4. Lista Nacional Oficial de Espécies da Flora Ameaçadas de Extinção. Diário Oficial da União, Brasília, 14 dez. 2014. Seção 0I, p. I2I. Disponível em: Acesso em: 10 nov. 2019.

CAO, X.; JIAO, Y. Control of cell fate during axillary meristem initiation. Cellular and Molecular Life Sciences, v. I, n. I, p. I-12, 2019.

CHINNARAI, S.; MALIMUTHU, C. Development of micropropagation and mini cutting protocol for fast growing Melia, Dalbergia and Eucalyptus clones for pulpwood and bioenergy plantations. BMC Proceedings, v. 5, p. I3I, 20 I I.

CORTE, V.B.; BORGES, E.E.L.; LEITE, H.G.; PEREIRA, B.L.C.; GONÇALVES, J.F.C. Estudo enzimático da deterioração de sementes de Melanoxylon brauna submetidas ao envelhecimento natural e acelerado. Revista Brasileira de Sementes, v. 32, n. I, p. 83-9I, 2010.

COSTA, A.O.; SILVA, L.A.S.; DUARTE, I.M.; MACHADO, M.; SILVA, G.Z.; SILVA, D.F. P.; COSTA NETTO, A.P.; ROCHA, D.I. Shoot proliferation and in vitro organogenesis from shoot apex and cotyledonary explants of royal poinciana (Delonix regia), an ornamental leguminous tree. Trees, v.34, p. 189-197, 2020.

COSTA, C.T.; ALMEIDA, M.R.; RUEDELL, C.M.; SCHWAMBACH, J.; MARASCHIN, F. S.; FETT-NETO, A.G. When stress and development go hand in hand: main hormonal controls of adventitious rooting in cuttings. Frontiers in Plant Science, v. 4, n. 133, p. I-19, 2013.

CREPALDI, M.O.S.; PEIXOTO, A.L. Use and knowledge of plants by "Quilombolas"as subsidies for conservation efforts in an area of Atlantic Forest in Espírito Santo State, Brazil. Biodiversity and Conservation, v. 19, n. I, p.37$60,2010$.

DELLO-IOIO, R.; LINHARES, F.S.; SCACCHI, E.; CASAMITJANAMARTINEZ, E.; HEIDSTRA, R.; COSTANTINO, P.; SABATINI, S. Cytokinins determine Arabidopsis root meristem size by controlling cell differentiation. Current Biology, v. 17, n. 8, p. 678-682, 2007.

DEWIR, Y.H.; NURMANSYAH; NAIDOO, Y.; SILVA, J.A.T. Thidiazuron-induced abnormalities in plant tissue cultures. Plant Cell Reports, v. 37, p. I45 I-1470, 2018.

DIERCK, R.; DHOOGHE, E.; HUYLENBROECK, J.V.; RIEK, J. D.; KEYSER, E. D.; STRAETEN, D.V.D. Response to strigolactone treatment in chrysanthemum axillary buds is influenced by auxin transport inhibition and sucrose availability. Acta Physiologiae Plantarum, v. 38, n. 27I, p. 2-II, 2016. 
DRUEGE, U.; FRANKEN, P.; HAJIREZAEI, M.R. Plant hormone homeostasis, signaling, and function during adventitious root formation in cuttings. Frontiers in Plant Science, v. 7, n. 38I, p. I-I4, 2016.

GARCIA-LUIS, A.; BORDÓN, Y.; MOREIRA-DIAS, J.M.; MOLINA, R.V.; GUARDIOLA, J.L. Explant orientation and polarity determine the morphogenic response of epicotyl segments of Troyer citrange. Annals of Botany, v. 84, n. 6, p. 715-723, 1999.

GEORGE, E.F;; HALL, M.A.; KLERK, G.J. Adventitious regeneration. In: GEORGE, E.F;; HALL, M.A.; KLERK, G.j. Plant propagation by tissue culture. Springer, Dordrecht, 2008. p. 355-40I.

GOEL, A.; KAUR, A.; KUMAR, A. Biochemical and histological changes during in vitro rooting of microcuttings of Bacopa monnieri (L.) Wettst. Acta Physiologiae Plantarum, v. 40 , n. 64, p. I-I2, 2018.

GUAN, L.; MURPHY, A.S.; WENDY, A.P.; GAN, L.; LI, Y.; CHENG, Z-M. (Max) Physiological and molecular regulation of adventitious root formation. Critical Reviews in Plant Sciences, v. 34, n. 5, p. 506-52I, 2015.

GUO, Y-X.; ZHAO, Y-Y; ZHANG, M.; ZHANG, L-Y. Development of a novel in vitro rooting culture system for the micropropagation of highbush blueberry (Vaccinium corymbosum) seedlings. Plant Cell, Tissue and Organ Culture, v. I, p. I-6, 2019.

HAO, Q.; ZHANG, L.; YANG, Y.; SHAN, Z.; ZHOU, X. Genome-wide analysis of the WOX gene family and function exploration of GmWOXI8 in soybean. Planta, v. 8, n. 215, p. I-18, 2019.

HARTMANN, H.T.; KESTER, D.E.; DAVIES JR, F.T.; GENEVE, R.L. Plant propagation: principles and practices. 8th ed. Boston: Prentice Hall, 20I I. 928 p.

HUSSAIN, S.A.; AHMAD, N.; ANIS, M. Synergetic efect of TDZ and BA on minimizing the postexposure efects on axillary shoot proliferation and assessment of genetic fdelity in Rauvolfa tetraphylla (L.). Rendiconti Lincei. Scienze Fisiche e Naturali, v. 29, p. 109-I I 5, 2018.

JHA, P.; OCHATT, S.J.; KUMAR, V. WUSCHEL: a master regulator in plant growth signaling. Plant Cell Reports, v. I, p. I-14, 2020.

KOECH, A.A.; ISUTSA, D.K.; WU, Q. Explants, hormones and sucrose influence in vitro shoot regeneration and rooting of calla lily (Zantedeschia albomaculata L. Spreng.) 'Black Magic'. Journal of Agriculture, Science and Technology, v. 7, n. I, p. 53-66, 2005.

LEE, J.M.; PIJUT, P.M. Adventitious shoot regeneration from in vitro leaf explants of Fraxinus nigra. Plant Cell, Tissue and Organ Culture, v. I30, n. 2, p. 335-343, 2017.

LEE, T.T.; STARRAT, A.N.; JEVNIKAR, J.J. Regulation of enzymic oxidation of indole-3-acetic acid by phenols: structureactivity relationship. Phytochemistry, v. 21, n. 3, p. 517$523,1982$.
LI, Z.; DING, Y.; XIE, L.; JIAN, H.; GAO, Y.; YIN, J.; LI, J.; LIU, $L$. Regulation by sugar and hormone signaling of the growth of Brassica napus L. axillary buds at the transcriptome level. Plant Growth Regulation, v. I, p. I- I4, 2020.

LLOYD, G.; McCOWN, B. Commercially feasible micropropagation of mountain laurel (Kalmia latifolia) by use of shoot-tip culture. Proceedings of the International Plant Propagation Society, v. 30, p. 42 I-427, 1980.

LONG, J.; BARTON, M.K. Initiation of axillary and floral meristems in Arabidopsis. Developmental Biology, v. 218, n. 2, p. 34I-353, 2000.

LORENZI, H. Árvores brasileiras: manual de identificação e cultivo de plantas arbóreas nativas do Brasil. Nova Odessa: Plantarum, 2009. 384p.

MAGYAR-TÁBORI, K.; DOBRÁNSZKI, J.; SILVA, J.A. da T.; BULLEY, S.M.; HUDÁK, I. The role of cytokinins in shoot organogenesis in apple. Plant Cell, Tissue and Organ Culture, v. I0I, n. 3, p. 25I-267, 2010.

MACKOVÁ, H.; HRONKOVÁ, M.; DOBRÁ, J.; TUREČKOVÁ, V.; NOVÁK, O.; LUBOVSKÁ, Z.; MOTYKA, V.; HAISEL, D.; HÁJEK, T.; PRÁŠIL, I.T.; GAUDINOVÁ, A.; ŠTORCHOVÁ, H.; GE, E.; WERNER, T.; SCHMÜLLING, T.; VANKOVÁ, R. Enhanced drought and heat stress tolerance of tobacco plants with ectopically enhanced cytokinin oxidase/dehydrogenase gene expression. Journal of Experimental Botany, v. 64, n. 10, p. 2805-2815, 2013.

MIYAWAKI, K.; TARKOWSKI, P.; MATSUMOTOKITANO, M.; KATO, T.; SATO, S.; TARKOWSKA, D.; TABATA, S.; SANDBERG, G.; AKAKIMOTO T. Roles of Arabidopsis ATP/ADP isopentenyltransferases and tRNA isopentenyltransferases in cytokinin biosynthesis. Proceedings of the National Academy of Sciences, v. I03, n. 44, p. 16598-16603, 2006.

MOREIRA-DIAS, J.M.; GUARDIOLA, J.L.; GARCÍA-LUIS, A. Daylength and photon flux density influence the growth regulator effects on morphogenesis in epicotyl segments of Troyer citrange. Science Horticulturae, v. 87, n. 4, p. 275-290, 2001.

NAAZ, A.; HUSSAIN, S.A.; NAZ, R.; ANIS, M.; ALATAR, A.A. Successful plant regeneration system via de novo organogenesis in Syzygium cumini (L.) Skeels: an important medicinal tree. Agroforest System, v. 93, n. 4, p. I2851295, 2019.

NUNES, E.C.; CASTILHO, C.V.; MORENO, F.N.; VIANA, A.M. In vitro culture of Cedrela fissilis Vellozo (Meliaceae). Plant Cell, Tissue and Organ Culture, v. 70, n. 3, p. 259-268, 2002.

PÉRET, B.; SWARUP, K.; FERGUSON, A.; SETH, M.; YAODONG, Y.; DHONDT, S.; JAMES, N.; CASIMIRO, I.; PERRY, P.; SYED, A.; YANG, H.; REEMMER, J.; VENISON, E.; HOWELLS, C.; PEREZ-AMADOR, M.A.; YUN, J.; ALONSO, J.; BEEMSTER, G.T.S.; LAPLAZE, L.; MURPHY, A.; BENNETT, M.J.; NIELSEN, E.; SWARUP, R. AUX/LAX genes encode a family of auxin influx transporters that perform distinct functions during Arabidopsis development. The Plant Cell, v. 24, n. 7, p. 2874-2885, 2012. 
PHILLIPS, G. C.; GARDA, M. Plant tissue culture media and practices: an overview. In Vitro Cellular \& Developmental Biology - Plant, v. I, n. I, p. I-I5, 2019.

RATHA, S.C.; SETH, S.; MISHRA, S.K.; YADAV, P.K.; GUPTA A.K.; PANIGRAHI, J. Genetic homogeneity assessment of in vitro-regenerated plantlets of Nyctanthes arbor-tristis L. and comparative evaluation of bioactive metabolites and antioxidant activity. In Vitro Cellular \& Developmental Biology - Plant, v. 56, n. I, p. 72-87, 2020.

R CORE TEAM. R: a language and environment for statistical computing, version 3.2.4. Vienna, Austria: R Foundation for Statistical Computing, 2017.

SCHINOR, E.H.; PAOLI, L. G.; AZEVEDO, F.A.; MOURÃO FILHO, F.A.A.; MENDES, B.M.J. Organogênese in vitro a partir de diferentes regiões do epicótilo de Citrus sp. Revista Brasileira de Fruticultura, v. 28, n. 3, p. 463-466, 2006.

SIRIL, E.A.; JOSEPH, N. Micropropagation of annatto (Bixo orellana $L$.) from mature tree and assessment of genetic fidelity of micropropagated plants with RAPD markers. Physiology and Molecular Biology of Plants, v. 19, n. I, p. $147-\mid 55,2013$.

SKOOG, F; MILLER, C.O. Chemical regulation growth and organ formation in plant tissues cultivated in vitro. Symposium of Society Experimental Biology, v. I I, p. II8-I3I, 1957.

SOARES, F.P; PAIVA, R.; ALVARENGA, A.A.; NOGUEIRA, R.C.; EMRICH, E.B.; MARTINOTTO, C. Organogênese direta em explantes caulinares de mangabeira (Hancornia speciosa Gomes). Ciência e Agrotecnologia, v. 3I, n. 4, p. 1048-1053, 2007.

SOUZA, R.R.; PAIVA, P.D.O.; SILVA, R.R.; SILVA, D.P.C.; REIS, M.V.; PAIVA, R. Morphogenetic potential of different sources of explants for efficient in vitro regeneration of Genipa sp. Plant Cell, Tissue and Organ Culture, v. I36, p. I53-160, 2019.
TAIZ, L.; ZEIGER, E.; MOLLER, I. M.; MURPHY, A. Fisiologia e desenvolvimento vegetal. 6 ed. Porto Alegre: Artmed, $2017.858 \mathrm{p}$.

US-CAMAS, R.; RIVERA-SOLÍS, G.; DUARTE-AKÉ, F; DELA-PEÑA, C. In vitro culture: an epigenetic challenge for plants. Plant Cell Tissue and Organ Culture, v. I 18, p. |87-20|, $20 \mid 4$.

UZELAC, B.; JANOŠEVIĆ, D.; STOJIČIĆ, D.; BUDIMIR, S. Effect of cytokinins on shoot apical meristem in Nicotiana tabacum. Archives of Biological Sciences, v. 64, n. 2, p. $5 \mid I-516,2012$.

VERSTRAETEN, I.; SCHOTTE, S.; GEELEN, D. Hypocotyl adventitious root organogenesis differs from lateral root development. Frontiers in Plant Science, v. 5, n. 495, p. I-I4, 2014.

VIBHA, J.B.; SHEKHAWAT, N.S.; MEHANDRU, P.; DINESH, R. Rapid multiplication of Dalbergia sissoo Roxb.: a timber yielding tree legume through axillary shoot proliferation and ex vitro rooting. Physiology and Molecular Biology of Plants, v. 20, n. I, p. 8I-87, 2014.

YANCHEVA S.; KONDAKOVA. V. Plant tissue culture technology: present and future development. In: PAVLOV A.; BLEY, T. (eds). Bioprocessing of plant in vitro systems. Phytochemical reference series. Springer, Cham. 2018. p. 39-63.

YANG, S.; YU, H.; XU, Y.; GOH, C.J. Investigation of cytokinin deficient phenotypes in Arabidopsis by ectopic expression of orchid DSCKXI. FEBS Letters, v. 555, n. 2, p. 29l-296, 2003. 